\title{
The Formation of a Criminal Inquisition
}

Durantis's Speculum iuris recognizes three types of criminal proceedings: accusation, denunciation, and inquisition. Accusatorial procedure held the injured party responsible for pursing the prosecution. Denunciation procedure occurred when an official, together with the injured party, made the complaint directly to the bishop (or judge), who moderated the trial. Inquisition procedure was an ex officio procedure initiated on the basis of the fama, or public knowledge, of the defendant's involvement in the crime. In practice, these processes did not remain in a neat triad, as elements of older procedures were incorporated into newer ones in ways that were often highly localized. ${ }^{1}$ By the fourteenth century, for example, the process of denunciation largely merged with inquisition, as denunciations made by officials, particularly the captains of urban neighborhoods or the consuls of the rural communes, initiated an inquisitio. ${ }^{2}$ Of the two criminal trial processes in use in Reggio' court, accusatio and inquisitio, accusatorial procedure was by far the more rare: of nearly a thousand surviving trials from 1373-1409, only seventeen used the older trial procedure of accusatio. ${ }^{3}$

Inquisition was overwhelmingly the dominant trial procedure used in the criminal court. The idea that inquisitorial proceedings could be used to prosecute all crimes, not just infamous ones, was proposed by Nicolaus de Matarellis

1 See the discussion in Trevor Dean, Crime in Medieval Europe, 1200-1550 (London: Longman, 2001), 7-10.

2 When Bartolus outlined the methods by which an inquisitorial trial could be initiated, he named first the denunciations made by public officials. Bartolus, Commentaria ad Dig. 48.5.2: "Primo, faciendo denunciatores et alios officiales, qui denunciant maleficia, quae committuntur, de quibus vidistis plene... Quandoque fit ista inquisitio per inspectionem oculorum. Vadit enim iudex personaliter et inspicit quaedam... Tertio modo sit per inquisitionem generalem, in qua inquiruntur latrones et alii male conditionis, et famae..."

3 Notaries sometimes used the verbs accusare and denunciare interchangeably, but there is no question of whether the trial record is that of an accusatorial trial or an inquisition. Private accusations begin with the appearance of the accuser before the judge (Coram nobis...). Inquisitorial trials open with a formulaic statement, described below, that begins Haec est quedam inquisitio....

(C) Joanna Carraway Vitiello, 2016 | DOI 10.1163/9789004311350_004

This is an open access title distributed under the terms of the Creative Commons AttributionNoncommercial-NonDerivative 3.0 Unported (CC-BY-NC-ND 3.0) License, which permits any noncommercial use, and distribution, provided no alterations are made and the original author(s) 
and developed by Bartolus. ${ }^{4}$ Throughout northern Italy, inquisition procedure had become a very common criminal trial procedure at the end of the fourteenth century. Inquisition procedure as practiced in these late medieval courts was a hybridized and flexible process that could incorporate elements from all three of Durantis's trial categories.

One of the clearest ways that we can see the transformation of inquisitorial procedure is by examining the many ways apart from publica fama that an inquisition could be initiated. Trial records from Reggio show a multitude of possibilities for initiating an inquisition. All inquisitions were technically $e x$ officio proceedings that emanated from public knowledge (publica fama) of the defendants' involvement with the crime, but frequently the records of the inquisitions also recorded additional sources of initiation, usually either the denunciation of a public official or the complaint (querela) of a private party. At Reggio, we find that while judges could and did inquire ex officio, more often they relied on the denunciations of local officials who were not in their direct employ and also the complaints of private parties, who made their accusations or complaints to the judge and posted surety for their claims. Especially the inquisitio ex querela maintained significant overlap with older accusatorial procedure, and this method of initiation represents a manifestation of the inquisitorial process that extended the scope of judicial authority while still often maintaining the participation of parties in conflict. ${ }^{5}$

\section{The Use of Private Accusatio Procedure at Reggio}

Of all the extant trial records in Reggio during the Visconti age, only seventeen were privately initiated accusatorial trials. In form, they are very distinct from inquisition trials. Aggrieved parties initiated the proceedings and presented the judge with accusations, which were formal charges probably prepared by professional advocates. In 1388, for example, a certain Antonius, son of Petrizolus,

4 Ullmann, "Some principles," 20. Bartolus further distinguished two kinds of inquisitorial procedure: inquisitio ad crimen inveniendum (also called inquisitio generalis, and inquisitio praeparatoria) which was the identification of crime and criminal, and the inquisitio ad crimen puniendum or inquisitio specialis, which was the stage of the process that we here refer to as the trial.

5 Stern, Criminal Law System, 24. At Florence, this flexibility served as an encouragement for accusations, as it probably did also at Reggio Emilia. 
denounced his wife Constanzia for adultery and for fleeing her home. Invoking the lex Iulia de adulteriis, he sought reparations for property that he claimed she stole (an estimate is included with the accusation) as well as the remission of her dowry. Antonius took an oath that he would prosecute the accusation to its conclusion, and not renounce it. This oath was sworn on his own life, and on all his goods present and future, sub obligatione sui et omnium suorum bonorum presentium et futurorum. ${ }^{6}$ Adultery was the most common crime prosecuted by private accusation (and ultimately the 1411 redaction of the statutes would require that all adultery cases be prosecuted by private accusation. $)^{7}$ One assault case proceeded with accusatio, ${ }^{8}$ and occasionally other types of conflicts used it too: when in 1403, Giberto da Fogliano accused two members of another branch of the Fogliano family of seizing possession of his castle at Levizzano, he did so with an accusation. ${ }^{9}$ Private accusation procedure was almost entirely replaced with inquisition procedure by the end of the fourteenth century at Reggio.

\section{Inquisitions ex officio}

In the most technical sense, all inquisitions are ex officio processes deriving from publica fama, as we clearly see in the formulaic statement that begins the trial, which reads as follows, with only the most minor of variations:

This is a certain inquest and notice of an inquest which is done, and which is directed to be done, by the above-written Lord Podestà and his Criminal Judge of the Commune of Reggio, by their office, judgment, and power... against [name of defendant] concerning the matter which comes to the ears and notice of the aforementioned Lords, the Lord Podestà and his Vicar, the Criminal Judge, for a hearing, with public fama

6 ASRe, Giudiziario, Libri delle denunzie, February 13, 1388 and following days, vol. 9, fols. $77 \mathrm{r}-78 \mathrm{v}$.

7 BSR, Statuti, ms. 77 , fol. $5^{11-v}$. The removal of the right of initiation from the judge's hands in adultery cases is contrary to Dean's findings that laws on matrimony increased in severity after the Black Death. Trevor Dean, "Fathers and Daughters: marriage laws and marriage disputes in Bologna and Italy, 1200-1500" in Marriage in Italy, 1300-1650, Trevor Dean and K.J.P. Lowe eds. (Cambridge: Cambridge University Press, 1998), 97.

8 ASRe, Giudiziario, Libri delle denunzie, November 11, 1375, vol. 2, fols. 109r-111v.

9 ASRe, Giudiziario, Libri delle denunzie, March 29, 1403 and following days, vol. 19, fol. 27r. On the context for this dispute, see Gamberini, La città assediata, 238-240. 
preceding and clamorous insinuations following and reporting back, not indeed by malevolent or slanderous or suspect persons, but rather by honest, truthful, and trustworthy persons ... ${ }^{10}$

If no further accuser was named, then the inquest was carried out ex officio: the judge's informant was apparently publica fama, and there was no named accuser. The role of fama as an accuser in inquisition procedure was extremely important, because it prevented the judge who initiated the trial from standing as the accuser and thus from becoming a party to the case, which was strictly forbidden by Roman law. ${ }^{11}$ Rather, the community in general stood as accuser, with fama as its voice. ${ }^{12}$ For Durantis, the rumor or common understanding ( fama) that a particular person had committed an act was sufficient to launch a criminal trial against that individual. In fact, Durantis allowed the accused to object to inquisition procedure if he was not infamous for the crimes with which he was charged: "If a prelate wishes to proceed to an inquisition against any person, that one against whom he wishes to inquire may object: 'My Lord, by law you cannot inquire against me, because I am not infamous concerning these crimes.' "13 By the end of the thirteenth century, fama was, in the words of Richard Fraher, "the procedural threshold that had to be surmounted before

10 ASRe, Giudiziario, Libri delle denunzie, June 16, 1373, vol. 1, fol. 8r: "Hec est quedam inquisitio et titulus inquisitionis que fit et fieri intenditur per superscriptos Dominos Potestatem et eius Iudicem Maleficorum comunis Regii, ex eorum officio, arbitrio, et baylia, et omni alio modo iuris via et forma quibus melius potest contra et adversus [name of defendant]. In eo, de eo, et super eo, quod ad aures et notitiam predictorum Dominorum Domini Potestatis et Vicarii Iudicis Maleficorum et utriusque eorum, fama publica precedente et clamosa insinuatione subsequenti et referente, non quidem malevolis maledictis nec suspectis sed potius ab honestis veridicis et fide dignis personis pervenit auditu ..." This transcription is from the first inquisition in the surviving records for this period at Reggio Emilia, but the form is standard. This formula, with only minor variations, was widely used. See Stern, "Public Fame...," 200.

11 Esmein, History of Continental Criminal Procedure, 81.

12 Fama was derived from the ius commune and was widely used as a trial initiator. In Florence, it was considered a reliable method of initiation and also, in some circumstances, of proof. Stern, "Public Fame in the Fifteenth Century," 206-207.

13 Durantis, Speculum iuris, Book III, part I, De inquisitione §1.1, p. 27: "Si enim prelatus velit procedere ad inquisitionem contra aliquem, opponat is, contra quem vult inquirere: Domine, non potestis contra me de iure inquirere, quia non sum de hiis criminibus infamatus." 
the inquisitorial magistrate could institute criminal proceedings ... analogous to the common law theory of probable cause."14

The judge's authority to instigate criminal proceedings ex officio on the basis of fama had been a major development in the scope of judicial authority. ${ }^{15}$ Yet there was a proverbial 'elephant in the room': could publica fama initiation provide a shield for capricious judicial action? How could publica fama initiations reach the ears of a foreign judge who was, at least theoretically, somewhat sequestered from the community? Perhaps to address these very concerns, the process of publica fama initiation was well organized in Florence, where witnesses appeared before the judge to testify to their indirect knowledge of a crime. ${ }^{16}$ At Reggio, witnesses frequently testified to fama after an inquisition was formed against a defendant, and probably this also happened during the course of criminal investigations, but there is no distinction at Reggio as there was at Florence between inquisitions initiated ex officio and inquisitions initiated by public fame.

The ability to inquire ex officio represented an important expansion of judicial authority, and perhaps for this reason, municipal statutes tended to place limits on the circumstances in which the judge could inquire ex officio. In thirteenth-century Perugia, for example, the instances in which a judge could act ex officio were limited to those cases that met the criteria for the use of torture: crimes of theft, attacks against communal order, and the usurpation of communal properties. The judge could also inquire ex officio over major assaults committed in the piazza of the commune. ${ }^{17}$ But in very general terms, there was a tendency in municipal courts to extend the judge's power to act ex officio to try most major felonies during the late thirteenth and especially the fourteenth century, and this is clear in the statutes at Reggio Emilia.

14 Richard Fraher, "Conviction According to Conscience: The Medieval Jurists' Debate Concerning Judicial Discretion and the Law of Proof," Law and History Review 7 (1989): 33 .

15 In fifteenth-century Florence, witnesses to publica fama could initiate an inquisition, and it was the most prevalent method of public initiation, distinct from ex officio initiations. For a full discussion of public initiation at Florence, see Stern, Criminal Law System, 22-27 and 203-211. At Reggio, publica fama is a named initiator in every inquisition trial. Only those trials, which do not include an additional denouncer or accuser-an official or a private party-, are here considered ex officio. There are no trials at Reggio that show witnesses initiating a proceeding by testimony to publica fama, though surely this was sometimes the impetus for ex officio actions, and witnesses to publica fama are frequent at the proof stage (as also at Florence).

16 Stern, "Public Fame in the Fifteenth Century," 198.

17 Vallerani, "How the Inquisition is Constructed," 252-253. 
At Reggio, the 1335 statutes (which were left in force after the Visconti takeover of the city in 1371, with only minimal changes) do not clearly define in which instances the judge could inquire ex officio, though it is impossible to say whether the ambiguity of the 1335/71 redaction limited the judge's power, or made it limitless. The 1392 redaction, however, included a new provision specifically obliging the Podestà and Criminal Judge to proceed on the denunciations they received, authorizing them to use ex officio procedure against any criminal discovered in the city or diocese. ${ }^{18}$ This could be interpreted as a significant expansion of power. ${ }^{19}$ Dramatic as this development appears, however, the impact of the statute was apparently minimal: prior to 1392, the Podestà only occasionally tried ex officio crimes that did not merit a blood penalty, and after 1392, the ex officio proceedings concerning less serious crimes continued to be rare. In fact, we might question whether the 1392 addition was really a real expansion of ex officio power at all, or just a codification of existing practice. Even after the apparently sweeping authority accorded to the judge in the 1392 redaction, one defendant successfully challenged the validity of a charge of insult made against him in an inquisitio ex querela by claiming that the judge did not have the right to proceed per inquisitionem in such a case. His crime was speaking injurious words against another man, and his advocate argued that the crime of insult is a minor crime (crimen iniuriarum sit leve crimen) and therefore the judge should not proceed by inquisition. In fact, because no one made an accusation, the defendant really should not be prosecuted at all, he continued, turning to Scripture for support: "whence Christ said to the woman, "If no one accuses you, I will not condemn you." (... unde legitur Christum dixisse mulieri, si nemo te acuxat [sic] nec ego te condempno). ${ }^{20}$

Real or illusory, the power given to the judge in 1392 to inquire ex officio in virtually every criminal case was somewhat moderated in the 1411 redaction of the statutes, which removed the question of ex officio procedure to its own rubric, and accorded to the judge the power to proceed ex officio in all cases that could incur a corporal penalty (pena sanguinis) and in cases than could incur a

18 ASRe, Comune, Statuti del 1392, fol. 157r: "Item, quod potestas et Iudex Maleficorum teneantur et debeant ad denuntiationem et notificationem cuiuslibet persone de comittatu Regii et etiam suo mero officio procedere contra quoscumque dellinquentes in Civitate vel in aliqua parte episcopatus Regii."

19 Gamberini, "La forza della comunità," 141. Gamberini notes this expansion of ex officio power as one of the significant changes to the penal law of the 1392 redaction.

20 ASRe, Giudiziario, Libri delle denunzie, July 20, 1398 and following days, vol. 18, fol. 27r. See Chapter Four for a further discussion of this case. 
pecuniary penalty of more than ten imperial pounds. ${ }^{21}$ The only exception was in cases of adultery, which were to proceed only by private accusation. ${ }^{22}$

This wide authority accorded to the judge to proceed in criminal matters was not unusual - such power was given to the judge by the statutes of Bologna a hundred years earlier. ${ }^{23}$ But it was also apparently not embraced. At Reggio, while such power rested with the judge at least since 1392 and probably much before, a strikingly small number of trials were actually initiated ex officio - only about 15 percent of inquisition trials. A minimum of one further notifier, either a public official or a private party or both, is recorded in 84.7 percent of inquisitions at Reggio. And Reggio Emilia was not unusual in this respect. At Bologna, Blanshei found, in a sample from 1326 of 132 trials, that only 16.6 percent proceeded ex officio. ${ }^{24}$ Vallerani also found at Perugia that a majority of inquisition trials were not instigated by the criminal judge. ${ }^{25}$ At Florence in the fifteenth century, Stern found ex officio initiation used in about 15.8 percent of trials. ${ }^{26}$ These numbers seem quite consistent.

If we consider the evidence as it relates to periods of signorial rule (remembering, however, that correlation does not equal causation) it is immediately noticeable that ex officio initiations appear at their lowest during the period of Giangaleazzo, even though the statutes appear to extend judicial authority for this sort of inquest at his direction. Under Barnabò, the rate of ex officio prosecution was higher than under Giangaleazzo and similar to that of the turbulent years of the rules of Giovanni Maria and Ottobuone. It is tempting to wonder if, in periods of great internal disturbance, like the initial years of Barnabo and Regina's rule, or like the period following Giangaleazzo's death, $e x$ officio procedure was used more often, either as a tool of crime control or as an assertion of power when that power was threatened or not yet stable.

BSR, Statuti, ms. 77, fol. 51r-v. The material was reorganized into two rubrics, De ordine procedendi in causis criminalibus and In quibus casibus possit procedi per officium.

22 At least three adultery cases proceeded by inquisition in the 1370's and 1380's.

23 Blanshei, "Criminal Justice in Medieval Perugia and Bologna," 255.

24 Blanshei, Politics and Justice, 344.

25 Vallerani, "How the Inquisition is Constructed," 228.

26 Stern, Criminal Law System, 204 and 207-208. In Florence, initiation by public famein which witnesses appeared before the judge to testify about the fama of a case, but with no direct knowledge of the facts - constituted a separate method of initiation that we do not find at Reggio. For this reason, even though the numbers of ex officio trials look very similar to Reggio and Perugia, the situation at Florence may not be immediately comparable to the situation at Reggio. On initiations, see Stern, Criminal Law System, 205-207. 


\section{Table: Notifications in 951 inquisition trials}

All inquisitions are ex officio and moved by publica fama. Most also include other means of initiation.

\begin{tabular}{|c|c|c|}
\hline Method of notification & Percentage of Trials & $\begin{array}{l}\text { Number out of } 951 \\
\text { inquisition trials }\end{array}$ \\
\hline Inquisitions ex officio ${ }^{27}$ & $15 \cdot 35 \%$ & 146 \\
\hline Inquisitions ex querela ${ }^{28}$ & $26.29 \%$ & 250 \\
\hline $\begin{array}{l}\text { Inquisitions initiated by a public } \\
\text { official. }\end{array}$ & $58.35 \%$ & 555 \\
\hline
\end{tabular}

Notifications during the signoria of Barnabò and Regina, from June, 1373July, 1382: (No trials survive from the second half of 1382 until October, 1385.)

\begin{tabular}{lll}
\hline Method of notification & Percentage of Trials & $\begin{array}{l}\text { Number out of 325 } \\
\text { inquisition trials }\end{array}$ \\
\hline Inquisitions ex officio & $22.15 \%$ & 72 \\
Inquisitions ex querela & & 64 \\
Inquisitions initiated by a public & $58.15 \%$ & 189 \\
official & & \\
\hline
\end{tabular}

27 Ex officio trials usually noted no other form of initiation besides publica fama. Sometimes, however, the notaries were more specific about the ways that the issue came to the judge's notice. I have included in the number of ex officio trials above two trials initiated ex alia informatione; four trials initiated ex confessione; one trial initiated ex contumacia et fuga; fourteen trials initiated ex diligenti informatione; five trials initiated ex informatione recepta; two trials initiated ex investigatione; two trials initiated ex testificatione.

28 This number includes three trials that the notary designated inquisitio ex acusa [sic]. In these trials, the accuser was the victim of the crime and the trial proceeded by inquisition. This number also includes 44 trials that were initiated both by querela and by a notification made by a municipal official.

29 This number includes two trials designated as inquisitio ex acusa, and seven trials that were initiated by both querela and a public notification. 
Notifications during the signoria of Giangaleazzo Visconti, from October, 1385-December, 1398. (No trials survive for the years 1399-1402.)

\begin{tabular}{lll}
\hline Method of notification & Percentage of Trials & $\begin{array}{l}\text { Number out of 517 } \\
\text { inquisition trials }\end{array}$ \\
\hline Inquisitions ex officio & $10.44 \%$ & 54 \\
Inquisitions ex querela & $29.01 \%$ & 150 \\
Inquisitions initiated by a public & $60.54 \%$ & 313 \\
official & & \\
\hline
\end{tabular}

Notifications during the signoria of Giovanni Maria Visconti and of Ottobuono Terzi, from November, 1402 until June, 1408:

\begin{tabular}{lll} 
Method of notification & Percentage of Trials & $\begin{array}{l}\text { Number out of 109 } \\
\text { inquisition trials }\end{array}$ \\
\hline Inquisitions ex officio & $19.26 \%$ & 21 \\
Inquisitions ex querela & $33.03 \%$ & 36 \\
$\begin{array}{l}\text { Inquisitions initiated by a public } \\
\text { official. }\end{array}$ & $47 \cdot 71 \%$ & $5^{2}$ \\
\hline
\end{tabular}

There were no clear characteristics that united trials that proceeded ex officio at Reggio. Ex officio trials do not dominate any one category of crime: murders, assaults, thefts, and all kinds of major crimes were sometimes initiated ex officio and sometimes initiated by a notification or complaint of an official or private party. Only a few general trends are noticeable that may distinguish these trials: more often than in trials initiated in another manner, ex officio inquisitions

30 This number includes one trial that the notary designated inquisitio ex acusa, and also includes 32 trials that were initiated both by querela and by a notification made by a municipal official.

31 Includes five trials that were initiated both by querela and by a notification made by a municipal official. 
dealt with serious crimes like murder, were more likely to address crimes committed within the city walls, and were more likely to be cases involving aggravating circumstances. ${ }^{32}$ But these generalizations are limited, and exceptions are easy to find.

Were inquisitions ex officio the result of direct investigative activity? Bartolus acknowledged the general inquisition (inquisitio generalis), as a way that inquisitions could begin, presumably ex officio. ${ }^{33}$ The inquisitio generalis was a regularly scheduled inquiry in which the municipal court sought denunciations of acts that should be prosecuted (as opposed to the inquisitio specialis, which today we would consider the trial, where a suspect was identified and accused). Gandinus's manual required such inquests to be conducted once monthly. ${ }^{34}$ At Reggio, there is little surviving evidence of the inquisitio generalis, though it seems likely that it was in use..$^{35}$ Judges could be and occasionally were involved directly in the investigation of crime, leading to an inquisition

32 While only seven percent of cases overall involved infamous criminals, 18 percent of cases brought ex officio did. The crimes in these cases are the most serious. Murder, which constituted nine percent of criminal cases overall, constituted 14 percent of ex officio proceedings. Insult and assault, which make up about $5^{6}$ percent of overall cases, constitute only 32 percent of cases tried ex officio. Of the crimes that were tried ex officio, 79 percent took place in the city itself, and 21 percent took place in the district. Overall, 70 percent took place in the city, and 30 percent in the district. Ten percent of cases tried ex officio were conducted against negligent or corrupt city officials; less than one percent of cases overall dealt with these kinds of crimes. Crimes committed at night were considered more serious and were more harshly penalized, sometimes incurring a doubled penalty. Of overall cases, nine percent concerned crimes committed at night; of cases conducted ex officio, 30 percent.

33 Bartolus, Commentaria, ad Dig. 48.5.2: "Primo, faciendo denunciatores et alios officiales, qui denunciant maleficia, quae committuntur, de quibus vidistis plene... Quandoque fit ista inquisitio per inspectionem oculorum. Vadit enim iudex personaliter et inspicit quaedam ... Tertio modo sit per inquisitionem generalem, in qua inquiruntur latrones et alii male conditionis, et famae..."

34 Massimo Vallerani, "Procedure and Justice in the Italian City-States of the Late Middle Ages: Twelfth-Fourteenth Centuries" in Medieval Public Justice, trans. Blanshei, ${ }^{2-53}$.

35 See for example ASRe, Giudiziario, Atti e processi, April 25, 1383, fol. 431r-v. This document is confirmation made by the communal nuncio that he had carried out his commission to make an announcement in the customary public places regarding the denunciation of crime. He delivered his message that neighborhood captains and consuls should "on the fifteenth day of the next month of May give satisfaction to the said office about homicides, assaults, quarrels, fights and whatever other crimes which happen to be committed and done in their borders... under a penalty decided by the discretion of the said Lord Podestà..." 
ex officio. Bartolus allowed that inquisitions could begin with the judge's direct knowledge of the crime, perinspectionem oculorum (literally, though awkwardly, "through the observation of his eyes"). ${ }^{36}$ In such instances, "the judge goes forth personally and inspects the matter."37 This method, in which the judge himself examined the scene of a crime to make his own deductions, appears only rarely in the material from Reggio Emilia. We find it used in 1392, when Nicholaus, son of Johannes de Flandria stabbed Antonius de Udino, a citizen of Reggio Emilia, during a fight and killed him. Though the fight took place near a crowded tavern, only one person testified, and he claimed that while he had not seen Nicholaus deliver the fatal blow, he had seen Nicholaus threaten Antonius with a knife. About the other witnesses, he insisted that he did not know any of their names. But when he was shown the murder weapon, he confirmed that it was the same knife he had seen in the fight. This alone could not, of course, constitute proof, but ultimately Nicholaus gave a full confession before the judge. ${ }^{38}$ The case itself had no extraordinary elements, and in the facts of the case as recorded in the statement of charges there is no obvious reason why the trial was initiated "ex inspectione oculata." However the crime took place "near a tavern, not far from the palace of the Lord Capitano ..."39 (iuxta barataria prope lobiam domini capitani). Perhaps it was for this reason that the judge himself investigated the crime scene and initiated the case against him. A marginal note indicates that ultimately Nicholaus was executed.

Criminal matters came directly to the judge in other ways as well, motivating him to begin an ex officio proceeding. Ex officio inquisitions could arise when a person was denounced in the confession of another criminal, (ex confessione) or in the testimony of a witness in another case (ex testificatione). Information could be divulged to the court through other unnamed methods, signified in the sources as ex informatione habita or ex diligenti informatione. A suspect might be identified through a judicial investigation, ex investigatione. In only one case was it noted that a person was prosecuted in absentia because he fled the scene of the crime (ex contumacia et fuga). ${ }^{40}$ In most cases,

36 The notary at Reggio recorded the initiation as ex inspectione occulata [sic], but the meaning is clearly the same.

37 Bartolus, Commentaria ad Dig. 48.5.2, "Quandoque fit ista inquisitio per inspectionem oculorum. Vadit enim iudex personaliter et inspicit quaedam ..."

38 ASRe, Giudizario, Libri delle denunzie, December 6, 1392, vol. 14, fols. 159r-6ov.

39 ASRe, Giudizario, Libri delle denunzie, December 6, 1392, vol. 14, fol. 159r.

40 ASRe, Giudizario, Libri delle denunzie, May 23, 1403, vol. 20, fols. 35-37v. Jurists had very serious concerns about prosecution or conviction in absentia. On conviction in absentia, see also Carraway, "Contumacy, defense strategy and criminal law." 
the notary simply stated that the inquisition was ex officio, and gave no further explanation.

Even in a small city like Reggio Emilia, judges scrutinized evidence, ordered investigations, and interrogated witnesses, but they were seldom directly involved in determining the suspect. Inquisitions ex officio were not the preferred path for judges. Far more commonly, municipal officials or even private parties carried out preliminary investigations and denounced malefactors.

\section{Public Officials and the Initiation of Inquisition Trials}

As we saw in the previous chapter, municipal officials had a primary role in the denunciation of crime at Reggio, and when judges proceeded with those denunciations, they did so through the path of an inquisitorial trial. When Bartolus outlined the methods by which an inquisitorial trial could be initiated, he named first the denunciations made by public officials. ${ }^{41}$ This was the most common method of initiation at Reggio, and again, Reggio was not unusual. In his study of late thirteenth century Bologna, Vallerani found that inquisition trials in late thirteenth century often began with an initiation from a policing official. ${ }^{42}$ In the majority of criminal cases at Reggio Emilia, a city official - usually a neighborhood captain or a consul or massario of one of the settlements under the jurisdiction of Reggio-notified the court of a criminal act, often after completing a preliminary investigation.

The trial records distinguish between a notificatio and a denunciatio made by civic officials, though the meaning of this distinction is unclear: the words appear to be used synonymously and interchangeably. The Latin denuntiare can carry the meaning of giving notice or announcing a fact-more akin to the English "notify" and less to the English "denounce." ${ }^{33}$ As the chart on page 61

41 Bartolus, Commentaria ad Dig. 48.5.2: "Primo, faciendo denunciatores et alios officiales, qui denunciant maleficia, quae committuntur, de quibus vidistis plene... Quandoque fit ista inquisitio per inspectionem oculorum. Vadit enim iudex personaliter et inspicit quaedam... Tertio modo sit per inquisitionem generalem, in qua inquiruntur latrones et alii male conditionis, et famae..."

42 Vallerani, "The Accusatory System in Action," 121. Alternatively, in Bologna inquisitions were initiated by the injured party in an inquisitio cum promovente. In Florence, only 17.5 percent of trials were initiated by a municipal official. Stern, Criminal Law System, 204.

43 Adolf Berger, The Encyclopedic Dictionary of Roman Law. The Transactions of the American Philosophical Society 43, part 2 (new series), 1953 (reprint 1991). s.v. "denuntiare." The Encyclopedic Dictionary of Roman Law states "... there was a denuntiare when a private person gave notice to another of a legally important fact..." Yet this definition 
demonstrates, denunciations and notifications made by these officials constitute by far the most common way that trials were initiated at Reggio Emilia during the Visconti period, with 58 percent of trials initiated by public officials. Additionally, 44 surviving trials ( 4.6 percent of the total), were initiated by both querelae and notifications made by public officials.

\section{Inquisitions Initiated by Private Parties}

The involvement of parties in conflict in inquisitorial procedure was clearly present by the end of the fourteenth century. In practice, we might doubt whether it was ever really absent. Victims of crime or their families were involved in denunciation not infrequently, having some role in the notification in 26 percent of the cases at Reggio. ${ }^{44}$ Again, Reggio was not unusual in this respect.

In late thirteenth century Perugia, private parties called promoventes could initiate inquisitorial trials, and Gandinus's Tractatus de maleficiis allows inquisition to proceed when a judge learned of wrongdoing through a private party (the promotor) who was aware of the mala fama of the crime "... the promotor of the inquisition should prove that he against whom the inquisition is formed is infamous concerning that crime." 45 The promotor was supposed to demonstrate that the accused was thought to be the perpetrator of the crime according to fama, and as such, the promotor bore some responsibility for the prosecution of the case. In Perugia, only the victim or victim's family was allowed to initiate inquisitions in an effort to limit false accusations. The majority of inquisition trials were not instigated by the criminal judge, and the use of the promoventes was common. ${ }^{46}$ Vallerani saw the use of private promoters in inquisition trials as an indication that inquisition was still in an "elastic" stage, with many similarities to accusation, suggesting that inquisition had not reached its full and mature development at the end of the thirteenth century. ${ }^{47}$

In Bologna, some inquisitions proceeded with the aid of a private party serving as coadiunctor. The person in this role filled many of the roles of the

does not encompass all the uses of denunciatio in Reggio's court, since denunciation did not always, or even usually, come from private parties.

44 Based on a sample of 773 cases where I have identified the notifiers.

45 Gandinus, Tractatus, 41. "... unde promotor inquisitionis debet probare, quod ille, contra quem inquiritur, sit de illo crimino infamatus." Cf. Vallerani, "Procedure and Justice," 49.

46 Vallerani, "How the Inquisition is Constructed," 250-252.

47 Vallerani, "The Accusatory System in Action," 120-122. 
accuser in the accusatorial trial, posting sureties for himself and the witnesses, and assuming much of the work of prosecution, even sometimes writing the interrogatories for the judge's interrogations. The notifier could act as the coadiunctor, but usually the coadiunctor was a relative of the victim. ${ }^{48}$ Sarah Blanshei also found a frequent use of notifications made by private parties in inquisition trials, which comprised 27.3 percent of the inquisitions of her 1326 sample. These private notifiers of inquisitions generally did not take on a prosecutorial role (though there were some exceptions). ${ }^{49}$

At the end of the fourteenth century at Reggio, the terms "promotor" and "coadiunctor" are not found in the trial records or statutes, but private parties, usually the victims or their family, could denounce crimes and instigate inquisitions. It is unclear whether only victims and their families could promote a prosecution, as at Perugia, because the subject is not addressed in the statutes, and sometimes the relationship between the named private party and the victim is not immediately apparent. Private parties could be involved in the prosecution of crime in three primary ways: either through accusatio procedure, though this process had largely fallen out of use; indirectly, by notifying a municipal official of crime, which would result in an inquisition initiated by that official; or directly, by initiating a prosecution and to some degree promoting it. When individuals denounced crime directly to the judge, their complaints to the judge are variously termed denunciations, notifications, accusations and complaints (querele). These terms appear to be used synonymously to describe the same process, with querela used most often.

It is in this practice of inquisitio ex querela that we can see most clearly the blending of inquisitorial and accusatorial processes. The initial stage of the process where the complainant directly approached the bench to make a criminal complaint is not well attested in the surviving documents from Reggio because this stage took place before the formation of inquests with identified defendants, which make up the bulk of archival judicial evidence. However a close look at the fragmentary surviving evidence together with the municipal statutes can shed light on this important process.

\section{Features of the Inquisitio ex querela}

We can find forerunners of the inquisitio ex querela in two and perhaps three earlier legal developments. First is the older accusatorial procedure, where

\footnotetext{
48 Blanshei, Politics and Justice, 345-355.

49 Blanshei, Politics and Justice, 344-345.
} 
private parties denounced their offenders before the criminal judge and undertook the costs and the obligations of the proceedings. Second is the involvement of private parties in the inquisition process in the late thirteenth century, either through the role of promotor or coadiunctor. The third potential ancestor for the inquisitio ex querela is a legal process that developed in Bologna at the end of the thirteenth century, which allowed private parties to bring a petition, called a querela, to the Consiglio del Popolo. In these petitions, the private party requested that the council give the judge permission to set aside some elements of due process and conduct the trial with an abbreviated summary procedure, or otherwise to proceed in cases where the law would not regularly allow it. ${ }^{50}$ The most important feature of these querele at Bologna was their function in seeking summary justice (and the concurrent ability of the Consiglio del Popolo to grant it). The power to set aside due process was a weighty one, and significantly, as Sarah Blanshei has demonstrated, the Consiglio del Popolo guarded this power carefully and considered each querela petition individually. ${ }^{51}$

While initially, these petitions were used by legally privileged persons, in 1320 the law changed, opening the door for anyone to make a formal complaint (querela) of crimes or property dispossessions to the Consiglio del Popolo. ${ }^{52}$ The 1320 legislative changes made the new querela petition process open to women as well as men, allowing broad access to this method of denunciation, and special meetings of the Consiglio del Popolo took place every month to deal with reviewing the petitions. ${ }^{53}$ The use of these querele was meant not only to safeguard against the power of magnates and nobles, but also to allow the justice system to function in spite of lengthy exceptions that could slow or stop the process. The querela represented "an instrument of recourse for those people who believed they have been treated unfairly by the law, or that the law had failed them."54

At the end of the fourteenth century, this process was no longer in use in Bologna. The term querela with respect to the criminal complaint referred, as it did at Reggio, to "complaints" made to the criminal judge as a means of initiating an inquisitorial trial. At first glance we may dismiss the parallel. After

\footnotetext{
$50 \quad$ Blanshei, Politics and Justice, 408.

$5^{1}$ Blanshei, Politics and Justice, 420.

$5^{2}$ This was clarified later in the year to state that while the process was open to many who were often excluded-including women — clergy, magnates and nobles were excluded from using the process. Blanshei, Politics and Justice, 442-444.

53 Blanshei, Politics and Justice, 445 .

54 Blanshei, Politics and Justice, 461.
} 
all, querela simply means "complaint", and it could and did have a wide range of meanings. And the Bolognese querela had procedural differences from that of later fourteenth century Reggio, because querela initiations at Bologna were presented to the judge after they had been approved by the signore and they contained directions for the proceeding of the trial (instructions to use summary procedure, or otherwise). But the criminal "querela" of the later fourteenth century also carried some of the same advantages for the complainant (querelator), opening the door to accusations by women and also allowing an injured party to seek summary procedure for his or her assailant. Whether it was a direct descendant from the earlier Bolognese querela process or not, the inquisitio ex querela at Reggio Emilia appears to serve many of the same functions. It is perhaps not unreasonable to speculate about the possibility of influence: statutes and policies in large cities tended to be influential in shaping policies in those of smaller areas, like Florence in Tuscany, and Bologna was influential in the region. ${ }^{55}$

The surviving evidence suggests four primary features of inquisitions cum querelis:

1. The querele which began trials were made by victims or their families, and these complaints could precede an official denunciation.

At Reggio Emilia, 26 percent of cases include a querela as a form of initiation. In querele, the victim or victim's family denounced the crime directly to the judge. In one of the few surviving records of this stage of the process, a certain notary and advocate named Filipus, son of Dominus Johannes de Malviciis, denounced Antonius de Albrixiis for speaking injurious words against him. ${ }^{56}$ In a timeless fit of outrage against the legal profession, in the middle of a court hearing Antonius had pointed at Filipus and cried, "A hundred men have been hanged who were not nearly as deserving as this Filipus!"57 Filipus himself appeared before the judge and the Podestà to make his complaint:

Before you, the distinguished noble man, the Lord Johannes de la Latri, honorable Podestà of the city and district of Reggio, and you, the distinguished doctor of law Gerardus de Rachellis de Parma, vicar and criminal judge of the lord Podestà, appeared Filipus, son of lord

\footnotetext{
55 Waley, "Use of Sortition in Appointments in the Italian Communes," 31.

$5^{6}$ ASRe, Giudiziario, Atti e processi, n.d., 1406, unnumbered folios.

57 ASRe, Giudiziario, Libri delle denunzie, June 9, 1406, vol. 21, 6or: "'Suspenduntur centum qui non essent ita digni sicut iste Filipus,' monstrando ipsum Filipum cum digito ...”
} 
Johannes de Malviciis, notary of the city of Reggio of the neighborhood of San Petrus, with a querela he expounds, names, and speaks against Antonius de Albrixiis... ${ }^{58}$

If we wonder why a person would choose to pursue a trial with a querela, rather than making the cheaper and safer denunciation to a municipal official, this moment of direct and public expression of enmity cannot be overlooked.

As noted above, frequently the same case was initiated by more than one method, and most, but not all, of the trials that were instigated by a querela also include a denunciation or notification by a city official. It is not always possible to know which came first, the querela or the official denunciation of the crime. When the order is clear, it seems that the querela was frequently the first means of denunciation. When in 1405, a certain Agnexina, daughter of Johannes de Cuvriaco, accused four men of raping her, she made a querela directly to the judge and her husband accompanied her to court where he made one too, though it is less thoroughly recorded. (The notary wrote only that "Johannes Puelus, miller and husband of the above-written Domina Agnexina, appeared [before the court] and concerning each and every thing written above, he made a complaint..." ${ }^{59}$ ) The next day, on December 29, 1405, the captain of the neighborhood of S. Maria Maddalena appeared in court to denounce and notify the accused men in this case. It is tempting to wonder if the neighborhood captain hurried to court to make his complaint after Agnexina made her querela to avoid appearing negligent. It is also possible that Agnexina and her husband simply went directly to the court of the Podestà and never involved the captain of their neighborhood, particularly considering the nature of the crime they wished to denounce.

$5^{8}$ ASRe, Giudiziario, Atti e processi, n.d., 1406, unnumbered folios. "Coram vobis egregio nobile viro Domino Johanne de la Latri honorabile potestate civitatis et districtus Regii et vobis egregio legum doctore Domino Gerardo de Rachellis de Parma vicario et iudice maleficorum nostri Domini Potestatis comparavit Filipus filius Domini Johannis de Malviciis notarius civitatis Regii vicine Sancti Petri et cum querela exponit nominat et dicit contra Antonium de Albrixiis ..."

59 ASRe, Giudiziario, Atti e processi, December 28, 1405, unnumbered folios: "Comperavit Johannes Puelus molinarius maritus superscripte Domine Agnexine et de superscriptis omnibus et singulis querelam fecit et querelatus fuit in omnibus et per omnia prout superius continetur." 
2. Those making querele bore some personal responsibility for the charges they initiated, including an oath and the posting of surety, similar to accusers in accusatio.

That those making the querela were required to post surety is clear from both redactions of the statutes that were in force during the period of this study. Both the 1335/71 and 1392 redactions require that "the accuser, denouncer, or person bringing the accusation upon which an inquisition can proceed" must present the charge in writing and then swear to the truth of their statement, providing surety concerning the prosecution of the charges in the form of a fideiussor, a person who appeared before the judge and guaranteed payment of expenses or fines (fideiussorem prestet de ipsa prosequenda). This may also have been the rule in Milan, where offended parties making denunciations to the judge and asking him to investigate may also have posted surety. ${ }^{60}$ The statutes at Reggio do not treat separately trials made by inquisition or accusation, describing only one general ordo iuris that pertains to all criminal trials. Persons initiating inquisitiones cum querelis, by statute, posted surety.

When the statutes of Reggio Emilia were revised in 1411 after the takeover of the Este, the book of criminal law was reorganized and elaborated. Among the new rubrics appears one that clarified the penalty for a person who made querela in criminal cases but did not pursue the charges until the end of the trial. The statute further directed that anyone who accused, complained against, or denounced anyone before the Podestà or his criminal judge concerning any crime or delict should suffer a penalty if the charge were not pursued, or if it were unproven. The penalties ranged from twenty-five Reggian lire for crimes that merited a blood penalty, to five pounds imperial for crimes that did not. Half of this money went to the accused, and the other half to the commune. The statute further allowed accusers ten days from the time of their denunciation to withdraw the charges. ${ }^{61}$ This probably was intended to overlap the ten

6o Verga, "Le sentenze criminali," 107-108. Verga did not reproduce the Latin text of his example but tells us that a complainant, inviting the judge to investigate whether her opponent had brought false witnesses against her in a civil case, swore the truth of her denunciation and presented two fideiussors.

61 BSR, Statuti, ms. 77 , fol. 65 v: "De pena querelantis non prosequentis vel non probantis accusationem vel denuntiationem factam. Si quis accusaverit querelaverit vel denuntiaverit aliquem coram potestate vel eius iudice mallificorum de aliquo malleficio vel delicto ex quo pena sanguinis venire imponenda et illam talem denuntiationem querellam vel accusam non probaverit vel non prosequtus [sic] fuerit usque ad sententiam, et lata fuerit sententia absolutoria talis accusans vel denuntians condemnet in libras xxv Rexanorum. 
days allowed in the 1335/71 and 1392 redactions for the making of the prosecutorial argument. The redactions of statutes in force for this study - the $1335 / 71$ and 1392 redactions — are silent about the penalty for a person making a querela who did not successfully pursue prosecution, but they do require that all who brought complaints (querele) to the criminal judge were required to post surety.

Trial records shed little light on the subject because surety was pledged when the initial denunciation was made before the judge, before the trial began. For evidence beyond the statutes, there are only sporadic references in trial records. But these references, rare as they are, suggest that the practice outlined in the statutes was followed, and in inquisitiones cum querelis during this period, the person bringing the complaint to the judge posted surety for the charge. If they were unable to pay, they may well have endured pre-trial imprisonment.

On January 17, 1393, a certain Giliola, wife of Andriolus de Rinalta, made a querela against Aluysinus de Fantis, claiming that "the said Aluysius, with a desire and intention of offending Giliola, made against her an assault, attack and violence (insultum, impetum et aggressuram), moving from place to place, running after her with a lance which he held in his hands; however he did not strike her."62 Three days later, Aluysius appeared before the judge and denied all the charges, irritably adding that everything in the charge was untrue, and Giliola should be the one prosecuted, not him. After his denial, Giliola was summoned before the judge. Giliola then returned to court and "on the occasion of a querela produced by her, this same Giliola promised to... follow this querela to the end, and for her part and at that time Andriolus [Giliola's husband]

Si vero accusa vel denuntia fuerit de crimine vel delicto ex quo pena sanguinis non ingeratur condemnet in libras v imperiales. Et in utroque dictorum casum accusator vel denuntiator in expensis accusato ven denuntiato quarum omnem condemnationem medietas perveniat accusato et alia medietas communi Regii. Et predicta non habeant locum in capitaneis vicinarum nec consulum villam qui denuntiarent aliquod malleficum. Possit tamen quilibet acusator [sic] querelator vel denuntiator a die producte accusationis querelationis vel denuntiationis infra dies decem impune desistere quantum est pro facto accusatoris denuntiatoris vel querelatoris."

62 ASRe, Giudiziario, Libri delle denunzie, January 17, 1393, vol. 14, fol. 164r: “... quod dictus Aluysius animo et intentione offendendi dictam Giliolam fecit insultum impetum et agressuram contra dictam Giliolam movendo se de locho ad lochum cum uno lanzono ferato quem suis manibus tenebat curendo [sic] post eam non tamen eam percussit." 
was her fideiussor." ${ }^{63}$ Aluysius was ultimately absolved, though there is no indication of what costs Giliola was required to pay.

It is possible that surety was required from Giliola because she was a married woman, and not because she made the querela. On the other hand, other trials instigated by the querele of married women do not record the posting of surety or the pledge to follow the case to the end. ${ }^{64}$ Rather, one wonders if her pledge of surety appears in the trial record not because it was an unusual practice, but rather because the posting of surety occurred unusually late - as we saw above, the statutes required the posting of surety when the denunciation was made, but Giliola did so late in the process, after the defendant had already appeared and denied the charge. In support of this view, we might consider that without question, accusers in private accusatio proceedings posted surety, but in only one instance was the name of the fideiussor recorded in the trial record. ${ }^{65}$ We should conclude either the practice of posting surety appeared in the statutes but was not used in practice-and especially in the case of accusation procedure, this seems highly unlikely - or the posting of surety by the accuser is not a process that is generally recorded in the extant trial records.

Another insight may be found in an inquisition for robbery that began in 1397 against two men, a certain Bartolinus and Johannes, initiated $e x$ querela et notificatione. The querela was made by the victim, a certain Gregorius de Placenta. The advocate for the defendants presented a complex defense to the judge in which he alleged a number of technical exceptions to the case, arguing that the judge should not proceed further with the inquisition. These reasons included a jurisdictional issue (the alleged robbery occurred in territory under the jurisdiction of Giberto da Fogliano) as well as procedural issues, including failure in the complaint to specify the exact place and precise day of the offense. And he also objected that the process violated both ius commune and statute law in

63 ASRe, Giudiziario, Libri delle denunzie, January 17, 1393, vol. 14, fol. 164v: "Constituta personaliter ... coram superscripto Domino Vicario et iudice Giliola predicta uxor Andrioli de Rinalta occaxione querele producta per ispam que Giliola promixit stare parere et cetera et prosequi dictam querelam usque ad finem. Et eius partibus et instantia fideiuxit et fideiussor extitit Andriolus..."

64 As, for example, ASRe, Giudiziario, Libri delle denunzie, April 12, 1388, and following days, vol. 10, fols. 16r-17r; ASRe, Giudiziario, Libri delle denunzie, October 29, 1388 and following days, vol. 12, fols. 49r-5or.

65 ASRe, Giudiziario, Libri delle denunzie, September 23, 1391, vol. 14, fol. 3v. 
part because Gregorius, the accuser, had not sworn to the truth of his accusation, and he had not posted surety (cum non promixerit iuraverit neque satisdederit superscriptus Gregorius de Placenta, prout debebat). ${ }^{66}$

If those who brought querela to the judge had to post surety-by 1411, a twenty-five pound surety for a blood crime-we must wonder about those who could not pledge such sums. A defendant unable to provide a fideiussor was imprisoned instead. Was this the case for accusers as well? A tantalizing glimpse into the practice of pre-trial confinement for accusers can be found, only by chance, in one of the very few surviving records of jail inmates at Reggio Emilia during this period. An undated order from the signore to expedite proceedings for certain inmates notes the reasons for each person's incarceration. Two entries are relevant here:

Andreas de Sancto Martino, detained because he was impugned concerning a certain homicide that was committed against the person of Brunamontis de Verona. We wish that justice should be done by expediting the process.

Codemanzius de Verona, detained because he accused the aforementioned Andreas, who still has not been found guilty concerning the said homicide. We wish that justice should be done by expediting the process. ${ }^{67}$

The trial record for this case survives, an inquisition initiated by querela in 1396 that is dated July 10, in which Codemanzius accused Andreas of attacking and robbing him and his friends, during which attack his father was killed. Andreas denied everything. ${ }^{68}$

Because the document above is undated, it is possible that Codemanzius was in jail because he made a private accusation against Andreas, and the order to expedite the process prompted the Podestà to form an

66 ASRe, Giudiziario, Libri delle denunzie, June 6 and following days, vol. 16, fols. 98r-10ov. In the end, none of the arguments—-procedural or jurisdictional-persuaded the judge, who convicted them. On the jurisdictional issue, see Gamberini, La città assediata, ${ }_{52}^{2-53}$.

67 ASRe, Giudiziario, Atti e processi, n.d. but probably 1396, unnumbered folios. "Andreas de Sancto Martino detentus quia inculpatus fuit de quodam homicido quod debuit commisisse in personam Brunamontis de Verona. Volumus quod ius fiat expediendo processum. Codemanzius de Verona detentus quia acusavit predictum Andream qui adhuc non est repertus culpabilis de dicto homicidio. Volumus quod ius fiat expediendo processum." ASRe, Giudiziario, Libri delle denunzie, July 10, 1396, vol. 15, fols. 105r-113r. 
inquisition. However, it would be highly unusual to have a homicide charge pursued by accusatio, as the process was virtually never used, and there are no surviving incidents of homicides tried with accusatio at Reggio. Furthermore, if the inquisition had been initiated by direct order from Milan, we might expect it to be an inquisition ex officio, not an inquisition ex querela. The trial record itself provides a clue to the date that the court at Milan requested the expedited proceeding. The inquisition against Andreas began on July 10, 1396, at which time the defendant appeared and denied all charges against him. He presented a defense claiming that he was a person of good reputation, and also that at the time of the murder, he was not in the territory where the crime was committed. He was able to produce witnesses to swear to his fama but not to his alibi, and he was put to torture in August of that year, still maintaining his innocence. On the 23rd of September he was subjected to torture again, this time withstanding rope torture as well as a sort of water torture, as large quantities of water and vinegar were poured into his nose. Still he refused to confess.

On November 17 of that year, an order arrived from Milan, which is copied into the trial document and which was written in response to an unrecorded inquiry from the Podestà. The letter ordered the Podestà to expedite the process, and it may well be a parallel to the order in the document above. The letter states further that Andreas should be tortured (for a third time!), and then the Podestà should make a decision whether to condemn him or absolve him and release him from jail. ${ }^{69}$ The letter is dated November 16, 1396. A marginal note tells us that he was released in December.

We cannot know how long Codemanzius sat in the same jail as the man he accused of murdering his father; it is a strange and dramatic image. And we should hesitate to make broad conclusions from one admittedly unusual case. Yet we can clearly see that in this instance, Codemanzius suffered the same pre-trial treatment as the man he accused, well before this practice appeared in the statutes of 1411. Finally, Codemanzius's imprisonment is nowhere noted in the trial record, underscoring once again that the accuser's posting of surety was recorded in another stage of the process that does not survive.

69 ASRe, Giudiziario, Libri delle denunzie, November 16, 1396, vol. 15, fol. 113r. "Volumus quod in facto isto faciatis ius expediendum et in quaestionem ipse Andreas veniat condempnandus eundem facti qualitate pensata condempnetis in quaestionem vero absolvendus veniat ipsum absolvatis a carceribus relaxari faciatis." 
Whether accusers posted surety is of great significance for our understanding of the late medieval inquisitorial trial. If the accuser in an inquisition ex querela had to post surety, one of the great innovations of inquisition procedure - the publication of the process and the removal of the burden of the trial from the victim - was not, at least in cases initiated by querela, fully in place. The older accusation procedure, accusatio, in which the victims or their representatives undertook the investigation and collected the necessary evidence, was encouraged in other cities like Florence, because it relieved the state of court costs, ${ }^{70}$ but if the inquisitions ex querela were similarly encouraged, there is no surviving evidence of this.

We are left to wonder whether the 1411 law concerning those who made querele but failed to prove their allegations was new, or whether once again, it codified an existing practice (and here again, it is worth remembering that the 1411 statues represent the first full redaction of the book of criminal law since 1335).

3. Complainants in inquisitiones ex querelis could ask the judge to proceed with summary procedure.

In the case of the notary Filipus and Antonius mentioned above, Filipus not only asked that Antonius be punished, but he even asked that the judge move against his foe with summary procedure,... dicit et petit ipse Filipus sibi fieri debere summarie et de plano sine streppitu [sic] et figura iudici ... ${ }^{71}$ This request, if granted, would allow the judge to evaluate the proofs and the allegations by his own conscience, without the formalities guaranteed by the ordo iuris. In the summary process, the judge "could gather and evaluate evidence beyond the allegations of the parties, and beyond the ordinary legal rules: any of his private knowledge could then lead him to intervene in a broader measure than in the ordinary process, although of course the evaluation of the evidence was always

70 Laura Ikins Stern, Criminal Law System, 22-23.

71 ASRe, Giudiziario, Libri delle denunzie, June 9, 1406, vol. 21, unnumbered folios: "Coram vobis egregio nobille viro Domino Johanne de la Latri honorabili potestati civitatis et districtus Regii et vobis egregio legum doctore Domino Gerardo de Rachellis de Parma vicario et iudice mallificorum nostri Domini Potestatis comparavit Filipus filius Domini Johannis de Malviciis notarius civis Regii vicine Sancti Petri et cum querela exponit nominat et dicit contra Antonius de Albrixiis..." The complaint and request for summary procedure also survives in ASRe, Giudiziario, Atti e processi, January 26, 1406, vol. 21, unnumbered folios. 
indispensable."72 The querela gave the accuser the possibility to seek summary procedure and to ask the judge to intervene in his dispute. In this case, the trial record has also survived, showing that the judge proceeded to try the case but did not do so by summary procedure. One wonders if, as in the similarly termed process at Bologna at the beginning of the fourteenth century, this possibility of seeking summary procedure was one of the benefits of the querela. ${ }^{73}$

4. Women used querele exclusively in their denunciations of crime.

Women could make querele as well as men, though they did so far less frequently: in cases initiated by the notice of a private party, only 7 percent of these accusers were women. But all of these cases were initiated by querele. In the surviving court records from Reggio, women never made denunciations or notifications to officials. They made only querele. For the most part, they reported major crimes: rape, murder, and major assaults. In all of these cases, the women themselves were the victims or relatives of the victims. That women made querele exclusively might indicate the limitations of their legal capacity, suggesting that they could not initiate an inquisition without surety.

What was the advantage of the inquisitio ex querela for the accuser? Why would injured parties choose to make denunciations directly to the judge, incurring

72 Antonio Padoa-Schioppa, Italia ed Europa nella storia del diritto (Bologna: il Mulino, 2003), 269. "Il giudice poteva raccogliere e valutare le prove anche al di là delle allegazioni delle parti e delle regole legali ordinarie: le sue eventuali conoscenze private potevano dunque condurlo ad intervenire in una misura più ampia che nel processo ordinario, benché naturalmente l'accertamento probatorio fosse pur sempre indispensabile."

73 In Reggio, there is no evidence that the Twelve or any other council ever had such a strong hold over the keys of summary justice as the Consiglio del Popolo had held at the beginning of the century in Bologna. In the later fourteenth century, criminal querele at Reggio were made directly to the judge, sometimes together with the Podestà, but there is no evidence to suggest that the municipal councils played a role. At Reggio, the statutes maintain a virtual silence on the responsibilities of the city councils that is unusual in cities under Visconti dominion, perhaps, as Gamberini suggested, because procedure was more easily modified when it remained customary and not codified; Gamberini, La città assediata, 77. The Twelve were charged with reviewing petitions, including so-called querele. However this term outside the context of the criminal court has many shades of meaning, and these are not necessarily criminal querele, as they are grouped together with other kinds of petitions. The council was convened by the Podestà and acted “... una cum dicto domino potestate et cum ipsius presentia et auctorite ..." ASRe, Comune, Carte di Corredo, October 22, 1383, vol. 2, fol. 1or. 
additional responsibilities, instead of making denunciations to municipal officials? Our surviving sources offer no direct answers, but our admittedly sparse archival evidence suggests that the inquisitio ex querela, while it may have entailed many financial and personal burdens, carried with it some advantages in the ability to seek summary justice, the possibility for women to make denunciations, and the public expression of enmity. At Reggio, the querele did serve as a platform by which the defendant could ask the judge for summary procedure, and in fact, it is very difficult to imagine that the victim would have the opportunity to make this request in the other types of trial initiations. If the petition for summary procedure was not granted, an inquisition ex querela where the accuser bore some of the burden for the trial, perhaps like a promotor or a coadiunctor, was instead performed, as in the case of Filipus and Antonius, described above. So the ability to seek summary procedure may have been part of the impetus behind the querela.

This answer is appealing, as it follows a line of thought descending from the early fourteenth century querela. But this does not really solve the riddle of those trials that were initiated by both a querela and an official notification. At Reggio, inquisitions ex querelis also served another function that might-in a very general and limited way - be compared with the function of the Bolognese querela of 1320 , as they certainly appear to open the door for people of virtually every background to make criminal complaints, and also were apparently the only avenue open for women to bring denunciations. For some victims, there may not have been another choice if the judge did not move ex officio.

There may well have been other, less quantifiable benefits to the querela, as it gave the victim a chance to become the aggressor, publicly pursuing charges and aiding in the prosecution of the opponent. This may be one more way that inquisition procedure incorporated the successes of accusation procedure and omitted, perhaps, its failures, as neither the late fourteenth-century initiators of querele, nor the Bolognese promoters, served the full prosecutorial role than an accuser would in accusatio. ${ }^{74}$ One of the most problematic features of the older accusatorial procedure was the ability of the accuser to withdraw charges after the initial citations of the defendant. As Vallerani has demonstrated, most accusatorial trials were stopped before their conclusion because the accuser, having achieved their end of publicly embarrassing their opponent, withdrew the charge. The inquisitio ex querela solved this problem by removing from the complainant the power to stop the proceeding once the judge initiated the inquest. At Reggio, trials were stopped before their conclusion only by a direct 
intervention from the lords of Milan. ${ }^{75}$ Accusers in the inquisitions ex querelis could not withdraw their accusations. So in this way, inquisition ex querela became a more efficient accusatorial process, one that carried with it considerable more risk for the accuser than the older accusatio process. Publicly standing as an accuser against an individual who caused some manner of personal injury may well have given the accuser an added — and highly desirablemeasure of public vindication for the damage, but there was little incentive to make a querela unless the aggrieved party wanted the case to be concluded.

As a final element in support of this idea that the inquisitiones ex querelis replaced the private accusation, we could note that the use of accusatorial procedure at Reggio was statistically insignificant-less than one percentwhereas at Bologna, where querele were used less often, accusation procedure was used more frequently, still following old patterns of trials initiated and then settled out of court. ${ }^{76}$ In a sample of 238 inquisition trials from four years of trial records of the criminal court of the Podestà in Bologna at the end of the fourteenth century, ${ }^{77}$ only 7.5 percent of inquisition trials were initiated by querela, as opposed to 26 percent at Reggio. Yet accusations made up 13.7 percent of trials at Bologna, compared with less than one percent at Reggio in the same period. Perhaps at Reggio, the adapted querele filled that need.

In many respects, it appears as if the person bringing the querela had strong parallels to the promotor of the thirteenth-century procedure. ${ }^{78}$ And if Vallerani's analogy between the inquisitio cum promovente and the earlier

75 The judge may have sometimes informally used his discretion to end a proceeding. For example, in 1379, Symon de Mutina made a querela against his brother Dominicus, claiming that he had hit him once without drawing blood. Dominicus appeared before the judge and admitted that he and his brother had argued, but he insisted that he did not strike him, and Symon, who was apparently also present, admitted under the judge's questioning that his brother had not hit him after all. Rather, he told the judge he had made the complaint because his brother had threatened him. There is no further record of the trial, and there is no marginal notiation of the outcome, as there are in most other trials of that register, leaving us to wonder if whether the record was somehow lost or incomplete, or if perhaps the judge simply sent the brothers home; ASRe, Giudiziario, Libri delle denunzie, June 13, 1379, vol. 5, fol. 55r-v.

76 Accusation procedure was in more frequent use at Bologna than at Reggio, but also at Bologna, its use was declining. Sarah Blanshei has demonstrated a substantial decline in its use during the fourteenth century, especially during the signoria of Taddeo Pepoli. Blanshei, “Cambiamenti e continuità nella procedura penale a Bologna," (forthcoming).

77 This sample is drawn from trial registers of the court of the Podestà. ASB, Curia del Podestà, Giudici ad maleficia, Libri inquisitionum et testium 1372, 1388, 1389, and 1393.

78 This term is not used in court records or statutes at Reggio, and it does not often appear in early fourteenth century Bologna, where generally the promotor seems "not to have 
accusation procedure is accurate-which I strongly support-then this is revealing for several different reasons. First, the overlap between accusation and inquisition in the thirteenth century was not simply a factor of the novelty of inquisitorial procedure. The almost complete absence of accusatorial procedure from the late fourteenth century record at Reggio Emilia indicates neither the triumph of inquisitorial procedure nor the centralized position of the judge, but rather the synchronizing of inquisition and accusation that perhaps began through the instrument of the promotor but soon transformed the process. That this fulfilled some of the needs of the earlier procedure finds support in its usage. For example, all forcible rape trials present in the records from this period at Reggio include a querela as the initiation of the trial. The one significant exception was prosecuted with a private accusatio.

A final benefit of the querela may have rested in its ability to force the court to proceed. Recent scholarship emphasizes the roles of parties in conflict shaping and using court procedures, but we must not ignore the very real power of the state that is reflected in inquisition: ex officio procedure gave the Podestà the right to act, but it also gave him the ability not to act. This is a complicated matter because of the very real questions we should have at this point regarding the agendas of the foreign rectors themselves. We cannot forget that the men who served as Podestà were often those same nobility whose disputes were decided and shaped with criminal and civil actions. And while it is true that most towns and cities preferred magistrates who came from a distance, this concept was relative. Reggio had many judges and officials, for example, from neighboring Parma. Reggian nobility served as Podestà, also, in Milan, Cremona, Parma, and elsewhere, like Giberto da Correggio, Podestà in Milan in 1392, or Gabriotto da Canossa, who earlier also held that position. In that capacity, they sometimes - as did Gabriotto, (see Chapter One) - oversaw cases directly pertinent to their own interests. Gabriotto, for example, as Podestà of Milan, ordered the ban of his own cousin Niccolò, who belonged to another branch of the family and who contested Gabriotto's possession of some castles in the eastern part of the territory of Reggio. ${ }^{79}$ It would be a mistake to assume neutrality.

By way of illustration, we can return to Gabriotto's murder, already discussed above in Chapter One concerning jurisdiction, to see how the instrument of inquisitio ex querela might find a politicized use. In the trial of Gabriotto's murderers, and in a later trial related to his heirs' claims for jurisdiction, the

served in the prosecutorial role that an accuser would perform in an accusatio." Blanshei, Politics and Justice, 344.

79 Gazata, Chronicon Regiense, col. 92. 
method of trial initiation reflected a greater political struggle. Gabriotto had been one of the most important and powerful lords of the contado. The city, perhaps relieved to be free of such a powerful local autonomous presence, was very slow to prosecute his murderers. The process of the trial itself reveals both Gabriotto's heirs' efforts to have vindication and the city's efforts to delay.

When Gabriotto's murder became known in Reggio, the Capitano della Città travelled to Bianello, but what happened next is a bit less clear: "he [the Capitano] had the castle freely given to him by Lord Niccolò [the murderer], and he led Lord Niccolò to the jail of the commune of Reggio; and likewise he [the Capitano] held the castle of San Paolo, and [these castles] came to the obedience of the Commune of Reggio..." ${ }^{80}$ Though the chronicler tells us that the Capitano went to Bianello when the matter became known (hoc audito) in Reggio, the initiation of the trial was not ex officio but was made by a complaint, a querela, made by Gabriotto's sons two months after the murder, and in fact, the visit of the Capitano to the castle is not mentioned in the record.

This was exactly the sort of case - a famous homicide, rumors of which were flying about the territory-that should have merited an inquisitio ex officio by any definition; the fact that the formal complaint was necessary to bring it to trial suggests a hesitation on the part of the court to act. In other words, the Podestà appeared to be dragging his feet in dealing with the murderers. The trial process, dated November 13,1385 , began nearly two months after the murder, and the condemnation was issued almost two months after that, on January $25,1386 .{ }^{81}$ According to the chronicler, it was in fact Giangaleazzo who ultimately ordered the execution of Niccolò and his son to proceed: the execution was done "by an order of the Lord Count (of Virtù), who desired that justice should be done." If this implies that the city hesitated to execute Gabriotto's murders, that sentiment would later be held also by Gabriotto's sons, who brought forward a charge in the Podestà's syndication claiming that he had allowed the other assassins to escape. ${ }^{82}$ Yet when a few years later, in the territory of Gabriotto's heirs at the castle of Montevetro, the woman

8o Gazata, Chronicon Regiense, col. 92-93: "et habuit dictum Castrum sibi datum per D. Nicolaum libere, et duxit Dominum Nicolaum ad carceres Communis Rhegii, et similiter habuit Castrum Sancti Pauli, et venerunt ad obedientiam Commuis Rhegii, quod fuit opus sanctissimum; et filii, et uxor dicti Dominus Gabrioti se reduxerunt in Montem-Vedrum. Hoc audito Dominus Comes mandavit, quod fieret ius Nicolao, et filiis D. Gabrioti, et quod dicta Castra obedient Civitati."

81 ASRe, Giudiziario, Libri delle denunzie, November 13, 1385, vol. 7 , fols. $82 \mathrm{r}-83 \mathrm{v}$. Of the six named defendants, four were contumacious; all were condemned, in person or in absentia, to death and the confiscation of their goods.

82 Gamberini, La città assediata, 46. 
Benevenuta was murdered by her husband, ${ }^{83}$ a denunciation was quickly made by the massario of the territory, and the court, eager to assert jurisdiction in the late Gabriotto's lands, now quickly formed an inquisition against Marchocius. ${ }^{84}$ The city pounced upon this case because it provided an opportunity to claim the sword of the merum imperium in these territories and to limit the jurisdictional claims of Gabriotto's heirs. If Gabriotto's sons used the querela to try to force the city to give justice to their father's murderers, the city, acting together with the Podestà's court, used an inquisition formed through official notification as a way of claiming a disputed jurisdiction.

So in addition to other benefits, such as seeking summary justice or publicly airing enmity, the instrument of querela may have been a useful tool in situations where, for his own reasons, the judge or Podestà failed to act. For most people, the idea of posting surety to force a trial that the judge already showed reluctance to prosecute may not have been an attractive proposition, but in other instances, it was a convenient tool to force prosecutions that were politically contentious.

\section{The Narrative of the Crime}

Whether an inquisition began ex officio, by an official notification, or through querele, the trial was an investigation of the assertions made in the largely narrative statement of the alleged wrongdoing that instigated the process. ${ }^{85} \mathrm{In}$ inquisitions ex officio, the statement of charges resulted from the judge's investigations or from reports made to him; in inquisitions, which were initiated by municipal officials, the narrative came from the reporting official. In inquisitiones ex querela, however, the statements of the charges represent the complaints of the victims, and in this sense, they might be easily compared to the libelli which initiated accusatorial trials. The formulation of the charges into a narrative statement might be done in the initial denunciation or complaint made to the judge, but when multiple officials or parties made complaints, which was frequently the case, it was the court's notary that created the

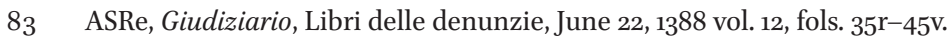

84 On this episode, see the discussion in Gamberini, La città assediata, 46.

85 In a civil trial, or in a criminal accusation, we would call this statement of the alleged facts of the case the libellus; when an official made a criminal complaint, we would refer to it as a denunciation; but there is no blanket term parallel to libellus for charges made in a criminal inquisition, which could be the result of one or more denunciations or complaints. I have used the phrase "statement of charges" to generally describe the opening of the inquisition that sets forth the narrative of the crime. 
narrative document. This was perhaps the most centrally important moment in the process, because the specific terms used indicated the degree of the felony, as well as particular circumstances which aggravated the severity of complaint, and taken together, this narrative was the foundation for the penalty if the accused were convicted.

The formulae used in the statements of charges gave a certain standardization to criminal complaints. Indeed, notaries used specific formulae for writing denunciations for particular crimes. This standardized the process and presented the key elements of the case that determined the nature or severity of the charge (such as force, per vim, in a rape charge). Notarial formulary books include exemplars for different kinds of denunciations, as well as defenses and exceptions. ${ }^{86}$ While these standardized practice and ensured systematic inclusion of key elements of the charges, they add a layer of obscurity for the modern historian trying to understand 'what happened,' as this formulary language abstracts and standardizes criminal actions. Vallerani noted formulaic statements and even dialogue inserted into the narrative. Within a six-month period, Vallerani found 116 instances of armed attacks that began with the aggressors' warnings: "Thief, it is necessary that I kill you!"87 And in these narratives, rapes frequently began with the attacker's admonishment: "I will kill you / I will cut off your nose, unless you are silent and permit me to do as I wish with your body." ${ }^{88}$ In the documents from Reggio, threats of death sometimes precede a sexual attack (see the discussion in Chapter Five) though we do not find the same formulary dialogue that Vallerani noted. However a host of formulae define the crime.

The statement of charges sets forth the primary elements of the crime, or substantialia. The Digest notes these elements as "the motive, the person, the place, the time, the quality, the quantity and the outcome." ${ }^{89}$ The person, place and time of the crimes were carefully described, including the nearest crossroads and neighboring houses of the crime scene. The quality of the act was indicated by the degree of severity, most obviously in the case of assault where the effusion of blood indicated the seriousness of the assaults, which were noted as sine effusione sanguinis, cum effusione sanguinis, or some variant of cum magna effusione sanguinis (which often, but not always, indicated a

86 See for example Guido Rossi, "Processus de Causis Civilibus et Criminalibus": Formulario Bolognese del Secolo XIII (Milan: A. Giuffrè, 1965). This is an edition of a series of processual acts by an unknown jurist that probably date from $1265^{-67}$ until 1282 .

87 The 116 examples are found in one semester's worth of trials from 1286. Vallerani, "The Accusatory System in Action," 129.

88 Vallerani, "The Accusatory System in Action," 130.

89 Dig. 48.19.16, quoted in Mayali, 312, and 312 n. 68. 
mortal wound). The quantity of actions is also indicated. For example, assault charges carefully inventoried the number of individual offenses made against the victim, and theft charges often included lists of items stolen. Defendants noted as vagabundi or robatores stratorum often had lists of charges against them that could go quite far back in time, ten or fifteen years. This list of charges going far back in time perhaps indicated recidivism, and it was also common in witchcraft trials.

Only motive, which seldom influenced punishment, was usually omitted. Sometimes records tell us that a crime occurred as part of a vendetta, which at Reggio could exacerbate the penalty, or give a set of circumstances leading up to an assault, but this information is rare. State of mind, however, could play a role in the outcome of the case. Most criminal cases address, in some way, the intention of the offender and his or her mental state. Hence in many cases we learn that an assault or an insult was committed when a defendant was enraged (irato animo). Intention distinguished accidents from acts committed with the purpose of harming or killing the victim. Premeditation is stressed with the formula "knowingly, and with a calculating mind, and with the intention of committing [the crime], and with a diabolical spirit." ${ }^{\prime 90}$ The worst crimesrobbery, murder, arson, rape and rebellion, but not assault—are denoted as "treacherously, knowingly, with deliberate and calculating consideration, and with a mind and intention of committing and perpetrating homicide, instigated by a diabolical spirit, not having God before his [or her] eyes, but rather the enemy of the human race...,", in indicating intention and premeditation of the worst sort. All these factors combined to determine the severity of the crime, upon which the judge would then render sentence.

\section{Citation}

The accusations made in the charges, including the details of the substantialia, were publicized in the citation process. ${ }^{92}$ The announcements of the nuncio

90 ASRe, Giudiziario, Libri delle denunzie, April 4, 1387, vol. 8, fol. 85r, here and elsewhere, "... scienter et appensate animo et intentione commitendi spiritu diabolico."

91 ASRe, Giudiziario, Libri delle denunzie, July 16, 1387, vol. 9, fol. 35r, here and elsewhere, “... dolose, scienter, deliberate tractate et appensate et animo et intentione homicidium comittendi et perpetrandi spiritu diabolico instigati deum pro occulis non habentes..."

92 See discussion in Peter Raymond Pazzaglini, The Criminal Ban of the Sienese Commune, 1225-1310 (Milan: Giuffrè, 1979). Chapter two, "Citation, contumacy and conviction," is devoted to this issue. 
were preceded by the blast of a trumpet, ensuring that not only the accused but also the neighbors of the accused were made aware of the accusation. ${ }^{93}$ The citation itself gave the particulars of the crime, including the time and place of the incident, the name of the judge and the day and hour at which the accused was cited, the name of the accused, and the name of the victim. Statutes dealt carefully with this important stage, requiring that the defendant be allowed not less than three days to respond to the summons, and also making concessions for other circumstances: foreigners were cited at the public assemblyplace of the commune and were given twice as long-six days-to respond, while charges against vagabonds were also publicly read at the assembly place of the commune, in lieu of a neighborhood or residence.

The formality and publicity of the announcements were a display of the court's jurisdiction and power. Beyond that assertion, the citation process served a very important function, allowing a failure to appear, or contumacy, to be interpreted as a deliberate act, and therefore as a justifiable ground for conviction in absentia. ${ }^{94}$ Approximately half the defendants cited to appear in Reggio's court were contumacious. The citation process allowed the court to frame the defendants' absence as a choice, and therefore, to proceed with a conviction in absentia.

The extant records seldom allow us to comprehend whether responses to citation procedure were voluntary or whether defendants were captured or detained. The records use the same formulaic statements in both cases, telling us only that the defendant appeared on a certain day before the judge (comperavit coram dictum dominum iudicem). The process followed the same lines either way, as the judge proceeded with the phase of inquisition that today we would term the trial— the inquisitio specialis.

\section{The Trial Process}

Court procedure and local norms for court procedure, which could have significant variations between towns, were defined in statute law, and occasionally in signorial decrees. We can summarize the beginning of the process as found in the procedural guidelines of the $1335 / 71$ and 1392 redactions as follows: ${ }^{95}$

\footnotetext{
93 BSR, Statuti, ms. 77, 52r: "De modo citandi illos contra quos proceditur."

94 Pazzaglini, The Criminal Ban of the Sienese Commune, 22.

95 ASRe, Comune, Statuti del 1335/1371, fol. 51r-v and ASRe, Comune, Statuti del 1392, fol. $147 \mathrm{r}-\mathrm{v}$.
} 
1. The accuser, denouncer, or person bringing the accusation upon which an inquisition can proceed must present the charge in writing to the Podestà or his judge.

2. That person must swear to the truth of the accusation and provide a fideiussor concerning the prosecution of the charges (fideiussorem prestet de ipsa prosequenda). The 1411 statutes clarify that public officials are not obliged to post surety; this almost certainly was already the common practice, which was incorporated into the full revision of the criminal statutes in this redaction. ${ }^{96}$

3. A term of ten days is assigned to the prosecution.

4. The accused (accusatus, denunciatus vel inquisitus) is cited by the communal nuncio.

5. The accused receives an appointed day to make an initial defense.

6. If the accused appears, the charge is read to him in the vulgar tongue, in secreto before the judge.

7. The accused swears to tell the truth and to purge himself (se purget) by affirming or denying the charges.

8. The accused offers any exceptions (technical objections to the charge against him or her, based on legal grounds).

9. The accused provides a fideiussor.

10. Ten days are allowed for the preparation of a defense, or fifteen days, if the accused lives outside the city.

11. Copies are made of the accusation (accuse, denunciationis et inquisitionis) for the accused.

In all cases, the accuser, denouncer, or person bringing the accusation upon which an inquisition can proceed must present the charge in writing to the Podestà or his judge and must swear to the truth of the accusation, providing a fideiussor concerning the prosecution of the charges, as we discussed above. ${ }^{97}$ This surety appears to be a necessary part of the procedure. The statutes make no distinction between the specific trial processes of accusation and inquisition, setting forward only one clearly delineated method of proceeding "to be observed concerning crimes and criminal processes, so that anyone who happens to be seriously accused, denounced, or inquired against

96 BSR, Statuti, ms. 77 , fol. $57 \mathrm{v}$, “... predicta non habeant in capitanei vicinae et consulum villarum civitatis burgorum districtus et episcopatus Regii ..."

97 ASRe, Comune, Statuti del 1335/1371, fol. 51r-v and ASRe, Comune, Statuti del 1392, fol. $147 \mathrm{r}-\mathrm{v}$. 
for any crime and any criminal case should come before the Lord Podestà or his judges...."98

The statutes, then, provided a broad ordo iuris that gave general outlines for any criminal trial, regardless of whether it were an accusation or an inquisition. This raises the question of whether, at the end of the fourteenth century, it would make more sense to distinguish between trials that were ex officio and trials that were not ex officio, rather than persisting in the traditional distinction between trials that were private accusations and trials that were inquisitions. Yet the criminal court's notaries pointedly retained that distinction between private accusation and inquisition, and it remains important not to lose the particular distinction that belongs to inquisition trial: the power of the inquiring magistrate. The logic of the older accusatorial trial versus the inquisitorial trial, whether ex officio or ex querela, was different. Vallerani compared the concept of facts in the triadic accusatorial process (accuser-accusedjudge) with that of inquisition in its pure, ex officio form. He wrote that the very facts at issue are reflected in, and to some extent determined by, the trial process: accusation seeks the truth of the disputed point through a dialectical process and confrontation between the parties' version of events, ${ }^{99}$ while the logic of the inquisitorial model seeks objective truth through a rational process. ${ }^{100}$ By the end of the fourteenth century, the inquisitio ex querela was a third element that bridged these ideas, still allowing confrontation, but leaving the power to investigate, call witnesses, weigh testimony, and render sentence firmly in the hands of an inquiring magistrate.

Though inquisitorial procedure had emerged as the dominant trial procedure by far at Reggio at the end of the fourteenth century, in fact inquisition was less replacing accusation than absorbing it through a series of technical procedural changes and adaptations that allowed inquisition procedure to fill those needs of confrontation and retribution that had actually been dealt with very effectively in accusatorial justice. The inquisitorial trial of the late fourteenth century developed the flexibility necessary to meet different and sometimes opposing needs: the needs of a court seeking to exert jurisdiction, both as a show of power and as an effort at crime control, and the needs of a culture and a people shaped by ideas of retribution, honor, and self-help.

\footnotetext{
98 ASRe, Comune, Statuti del 1335/1371, fol. 25r: "In maleficiis et maleficiorum processibus talem ordinem duximus observandum ut quencumque enormiter aliquem accusari denunciari vel inquiri pro quocumque maleficio et maleficii causa coram domino potestate vel eius iudicibus contingerit [sic] ..."

99 Massimo Vallerani, "How Procedures Think: Facts and the Trial," in Medieval Public Justice, trans. Blanshei, $77-78$.

100 Vallerani, "How Procedures Think," 80.
} 